\title{
Analysis of creatine kinase and alpha-actin concentrations in soccer pre-season
}

\section{Análise das concentrações de creatina quinase e alfa -actina no futebol pré-temporada}

\author{
PIMENTA, E; COELHO, D. B.; CAPETTINI, L; GOMES, T; PUSSIELDI, G; \\ RIBEIRO, J; GOMES-FILHO, A; SILAMI-GARCIA, E. Analysis of creatine kinase \\ and alpha-actin concentrations in soccer pre-season. R. bras. Ci. e Mov 2015;23(4):5- \\ 11.
}

\begin{abstract}
Purpose: The purpose of the present study was to assess muscle overload through changes in creatine kinase (CK) activity and serum concentration of $\alpha$-actin in soccer players in response of two months of pre-season physical training. Basic procedures: Ten professional athletes ( $26 \pm 6$ years of age) undergoing arduous training were evaluated. Serum CK activity and $\alpha$-actin serum concentration were determined at the beginning and end of two months of pre-season training. Effort intensity was determined throughout the training sessions by monitoring heart rate (HR). Serum CK activity was determined using the colorimetric method. Plasma $\alpha$-actin concentration was evaluated using ELISA and confirmed using the Western Blot method. Main Findings: Serum CK activity and $\alpha$-actin concentration were higher in the post-training period in comparison to the pre-training period (CK: PRE $65.5 \pm 4.2 \mathrm{U} / \mathrm{L}$, POST $435.7 \pm$ $70.0 \mathrm{U} / \mathrm{L}, \mathrm{p}=0.0004 ; \alpha$-actin by Western Blot: PRE $42.9 \pm 21.6 \mu \mathrm{g} / \mathrm{mL}$, POST $68.1 \pm 19.1 \mu \mathrm{g} / \mathrm{mL}$, $\mathrm{p}=0.0004$; by ELISA: PRE $70.63 \pm 10.4 \mu \mathrm{g} / \mathrm{mL}$, POST $101.80 \pm 17.3 \mu \mathrm{g} / \mathrm{mL}, \mathrm{p}=0.0125$ ). Conclusions: The significant increases in $\alpha$-actin concentration and in CK activity of soccer players over the two-month pre-season indicated that an elevated training overload was imposed upon the athletes.
\end{abstract}

Key Words: Muscle Damage; Creatine Kinase; Training Monitoring.
Eduardo Pimenta ${ }^{1}$ Daniel Barbosa Coelho ${ }^{1}$

Luciano Capettini ${ }^{1}$ Thales Gomes ${ }^{1}$ Guilherme Pussieldi ${ }^{1}$ Jose Ribeiro ${ }^{1}$ Ary Gomes-Filho ${ }^{1}$ Emerson Silami-Garcia ${ }^{1}$

${ }^{1}$ Universidade Federal de Minas Gerais

RESUMO: Objetivo: O objetivo do presente estudo foi avaliar a sobrecarga muscular através de mudanças na creatina quinase (CK) e concentração sérica de $\alpha$-actina em jogadores de futebol de resposta de dois meses de treinamento físico de pré-temporada. Procedimentos básicos: Dez atletas profissionais ( $26 \pm 6$ anos de idade) que se submeteram aos treinamentos foram avaliados. Atividade de CK e concentração sérica de actina- $\alpha$ foram determinados no início e no fim de dois meses de treinamento de pré-temporada. Intensidade de esforço foi determinada ao longo das sessões de treinamento por meio do monitoramento da freqüência cardíaca (FC). Actividade de $\mathrm{CK}$ no soro foi determinada pelo método colorimétrico. Concentração de plasma $\alpha$-actina foi avaliada utilizando ELISA e confirmado usando o método de Western Blot. Conclusões: a atividade da CK sérica e concentração $\alpha$-actina foram maiores no período pós-treinamento em comparação com o período pré-treinamento (CK: PRE 65,5 \pm 4,2 U/L, 435,7 $\pm 70,0$ POST U/L, $\mathrm{p}=0,0004 ; \alpha$-actina por Western Blot: PRE 42,9 $\pm 21,6 \mathrm{ng} / \mathrm{mL}, 68,1 \pm 19,1$ POST $\mathrm{mcg} / \mathrm{mL}, \mathrm{p}=0,0004$; por ELISA: PRE 70,63 $\pm 10,4 \mathrm{ng} / \mathrm{mL}$, POST 101,80 $\pm 17,3 \mathrm{ng} / \mathrm{mL}, \mathrm{p}=0,0125$ ). Conclusões: $O$ aumento da atividade da CK e da concentração de actina- $\alpha$ após dois meses de treinamento na pré-temporada de um time de futebol indica uma sobrecarga muscular significativa imposta por este período de treinamento.

Palavras-chave: Dano Muscular; Creatina Kinase; Monitoramento De Treino.

Recebido: $18 / 05 / 2014$ Aceito: 18/02/2015

Contato: Eduardo Pimenta - empimenta@uol.com.br 


\section{Introduction}

Considering the progressive increase in the competitiveness of the team sports, especially soccer, trainers, coaches and researchers have continuously searched for innovations in the investigation of parameters that can evaluate and control the level of training for the assessment of adaptation to training loads as well as recovery. The recovery status of athletes should determine the characteristics of the training program in order to avoid the underestimation or overestimation of this aspect. Long training periods or very intense training may trigger an overtraining process, leading to a decline in sport efficiency arising from physiological and psychological disorders, which may lead the athlete to a temporary (burn-out) or a permanent (drop-out) abandonment of the sport ${ }^{1}$.

Markers of muscle damage have been used as parameters of the recovery status of athletes. Indirect methods are most commonly used in such studies due to the ease of the data collection and low coast in comparison to direct methods. The enzymes creatine kinase $(\mathrm{CK})$ and lactate dehydrogenase (LDH), fragments from the myosin heavy chain (MHC), troponin-I, myoglobin and $\alpha$-actin are well known markers, as they are cytoplasmic molecules and do not have the ability to cross the sarcoplasmic membrane ${ }^{2}$. Thus, an increase in the plasma concentration of these molecules is used as an indicator of muscle membrane injury ${ }^{3}$. When the muscle membrane is injured during the practice of physical activity, the cell membranes are ruptured and sarcoplasmic molecules, such as the CK and the $\alpha$-actin, migrate to the bloodstream ${ }^{4}$.

CK activity represents the mechanical wear of the muscle resulting from training sessions in the previous days related to the training intensity and volume, especially when eccentric exercises are performed with a non-adapted muscle system ${ }^{7}$. CK is often described as a good indirect marker of muscle damage, mainly after strength training or other exercises that require predominantly eccentric actions ${ }^{2,8,9}$. However, CK should not be used as the only marker of muscle damage, as it has been demonstrated that its activity may not be increased in the serum of animals submitted to highly intensive physical exercise ${ }^{10}$.

In the past few decades, we witnessed great advances in science and technology applied to soccer, which allows sports scientists to evaluate the physiological overload imposed upon the players. Many parameters, such as heart rate and the total distance covered by the athletes during a game or a training session, as well as the number of sprints and accelerations, can now be measured thanks to modern equipment which is now available. Likewise, many other variables such as oxygen consumption, time of play, time spent on physical, technical and tactical workouts, to name a few, are also ordinarily monitored ${ }^{11-13}$. More recently, biochemical parameters have also gained importance in the control of acute $e^{14-16}$ and chronic $^{17,18}$ training overload in soccer. These parameters have been found to be associated to overtraining. A reduction of $30 \%$ or more in the resting testosterone/cortisol ratio $^{19}$ and $\mathrm{CK}$ values above 950 $\mathrm{U} / \mathrm{L}^{18}$, for example, are considered overtraining markers at any time during the competitive season.

The pre-season in Brazil takes place immediately after a 30-day vacation period, during which the level of physical conditioning of the athletes usually goes down significantly. During this period players are subjected to heavy training sessions which include physical tests and usually two sessions of very intensive training every day, for about three weeks. Significant changes in biochemical markers of physiological stress have been reported in soccer players during the pre-season ${ }^{20}$, and therefore individualized control of training overload becomes an important tool for reducing the incidence of muscle injuries.

Recently, $\alpha$-actin has been also proposed as marker of muscle damage, because it is a structural protein of the musculoskeletal system that is released quickly into the blood in cases of muscle damage with no interference from other tissues and it remains at high concentrations for 72 hours. $\alpha$-actin is abundant in the cytoplasm at higher concentrations than other markers and has an isoform specific to skeletal muscle. As a 
structural protein directly involved in the muscle contraction process, $\alpha$-actin has been suggested as a specific marker of muscle injury in athletes. Moreover, the identification of $\alpha$-actin is slightly affected by injuries in other tissues ${ }^{21}$.

The purpose of the present study was to assess muscle overload through changes in CK activity and serum concentrations of $\alpha$-actin in soccer players in response to two months of pre-season physical training.

\section{Methods}

\section{Subjects}

This study received approval from the Ethics Committee of the Universidade de Itaúna - MG, Brazil, under registration $\mathrm{n}^{\circ}$. 006/08. Initially, 23 male athletes from 19 to 34 years of age in the professional category of a first division Brazilian soccer team took part in this study. As a result of the departure of some athletes, the final sample was reduced to 10 subjects. All athletes were informed about the proceedings to which they would be submitted and signed terms of informed consent. Athletes who attended less than $60 \%$ of the training sessions were excluded from the study. The athletes' diet was controlled by the department of nutrition of the club throughout the period and every medication used by the athletes was properly recorded. Table 1 displays the characteristics of the sample.

The first data collection (PRE) occurred when the athletes first showed up for training following a vacation period. The second collection (POST) was performed at the end of the two-month pre-season training, 36 hours after the third game of the state competition. At both times, blood collection was performed in the morning (7:00 to 9:00 h) before training, when the athletes were fasting.

The blood used for biochemical analysis was collected from the antecubital vein, using EDTA blood collection vacuum tubes (Vacuette ${ }^{\circledR}$ ). Immediately after collection, the tubes were centrifuged at $1500 \mathrm{~g}$ for 10 $\min$ at $4^{\circ} \mathrm{C}$, and the $0.5 \mathrm{~mL}$ serum aliquots were stored at $-80^{\circ} \mathrm{C}$.

\section{Plasma CK activity}

The analysis of plasma CK activity was performed using the MPR3 CK NAC-activated kit (Boehringer Mannheim).

\section{Protein expression of plasma $\alpha$-actin by Western Blot analysis}

The samples were centrifuged at $8000 \mathrm{rpm}$ for 10 minutes. After protein dosage, the samples were diluted in a cocktail of protease inhibitors (AEBSF $2 \mathrm{mM}+$ EDTA $1 \mathrm{mM}+$ bestatin $130 \mu \mathrm{M}+\mathrm{E} 6414 \mu \mathrm{M}+$ leupeptin $1 \mu \mathrm{M}+$ aprotinin $0.3 \mu \mathrm{M}$; SigmaFast $^{\circledR}$, Sigma) to obtain a final protein concentration of $1 \mathrm{mg} / \mathrm{mL}$. The amount of proteins was determined based on the method described by Lowry ${ }^{22}$.

The samples were diluted in the buffer $(4 \mathrm{X}$ tris $\mathrm{HCl} / \mathrm{SDS} \mathrm{pH}=6.8,3 \%$ Glycerol, $1 \%$ SDS, $0.6 \% \quad \beta-$ mercaptoethanol, Bromophenol Blue). For separation, 15 $\mu \mathrm{g}$ of gel protein of SDS-PAGE (sodium dodecyl (lauryl) sulfate-polyacrylamide) were administered at concentrations of $10 \%$. The separation was performed with a tension of $110 \mathrm{~V}$ for approximately $1.5 \mathrm{~h}$. After separated in the gel, the proteins were transferred to a PVDF (Millipore ${ }^{\circledR}$, USA) membrane with pore of 0.45 $\mu \mathrm{m}$. The quality of the transference was monitored through membrane staining with $0.3 \%$ Ponceau solution. The membrane was washed in distilled water and inserted for one hour in a blocking solution (TBS-Tween $0.1 \%$ with $2.5 \%$ powdered skim milk). The membrane was then incubated for one hour at room temperature with the primary monoclonal antibody anti- $\alpha$-actin diluted at 1:1000 (Sigma, St. Louis, USA). The membrane was washed with TBS containing $0.3 \%$ Tween 20 (TBS-T) for five minutes three times and incubated for two hours with the secondary antibody conjugated to the peroxidase (HRP) (1:2000, anti-mouse IgG-HRP, Sigma, St. Louis, USA). After the incubation period, the membrane was washed again in TBS-T for five minutes three times. The protein bands were detected by a chemiluminescence reaction (kit ECL plus - Amersham Biosciences do Brasil Ltda) and intensities were assessed through densitometric analysis by the ImageQuant ${ }^{\mathrm{TM}}$ program. 


\section{Dosage of a-actin by Enzyme Linked Immunoabsorbent Assay (ELISA)}

Interleukin 6 (IL-6) plasma levels were measured using the ELISA

method with a high-sensitivity kit (QuantikineR HS, R\&D Systems Minneapolis, MN, USA).

The alpha-actin was measured using the ELISA method, in which plasma samples were diluted in an adequate buffer (coating buffer; composition in $\mathrm{g} / \mathrm{L}$ : $\mathrm{Na}_{2} \mathrm{CO}_{3}$ 1.59; $\mathrm{NaHCO}_{3}$ 1.93; pH 9.6). Ninety-six well plates were sensitized with $100 \mu \mathrm{L}$ of the serum samples for a period of approximately $12 \mathrm{~h}$ at $4{ }^{\circ} \mathrm{C}$. All the liquid was then removed from the plates and they were lightly washed with a washing buffer $(0.9 \% \mathrm{NaCl}+0.05 \%$ Tween-20).

A block of nonspecific connections was performed through the addition to each well of $100 \mu \mathrm{l}$ of PBS plus $2 \%$ skim milk (Molico) for one hour at $37^{\circ} \mathrm{C}$. The plate was washed once more with the washing buffer and the primary monoclonal antibody anti- $\alpha$-actin (Sigma, St. Louis, USA) diluted at 1:1000 in PBS-T (PBS + 0.05\% Tween-20). After incubation for one hour at $37{ }^{\circ} \mathrm{C}$, the primary antibody was removed, the plate was washed again and the secondary polyclonal antibody anti-mouse diluted at 1:3000 PBS-T $+2 \%$ milk was added to the solution. Two washes were performed and a reaction substrate (OPD $0.2 \mathrm{mg} / \mathrm{mL}$ in citrate buffer $5.2 \mathrm{~g} / \mathrm{L}, \mathrm{pH}$ 5.0) was added. After 20 minutes, the reaction was stopped with $20 \mu \mathrm{l}$ of $\mathrm{H}_{2} \mathrm{SO}_{4} 4 \mathrm{~N}$ and the reading was performed with a microplate reader at $492 \mathrm{~nm}$ (Biotek ELX $800^{\circledR}$ ). Negative (only coating buffer) and positive $(10 ; 5 ; 1 ; 0.5 \mu \mathrm{g}$ of $\alpha$-actin) controls were carried out. The plasma $\alpha$-actin concentration was calculated based on a previously established $\alpha$-actin pattern.

\section{Training monitoring}

Training intensity was determined by monitoring the heart rate (HR) during the activities with the use of heart monitors (Polar ${ }^{\circledR}$ Electro Oy, Polar Team System, Finland). Training intensity was determined as a percentage of maximal HR and percentage of maximal oxygen uptake $\left(\mathrm{VO}_{2 \max }\right)$. The estimation of oxygen consumption of the activities was obtained from the HR$\mathrm{VO}_{2}$ ratio after a test of aerobic capacity carried out in the laboratory.

\section{Determination of aerobic capacity}

The progressive exercise test was performed on a treadmill (Inbramed Millennium ${ }^{\circledR}$ ) to determine $\mathrm{VO}_{2 \max }$ was composed of one-minute stages, with an initial velocity of $4 \mathrm{~km} / \mathrm{h}$ and a constant slope of $2 \%$ until reaching $15 \mathrm{~km} / \mathrm{h}$. The speed was then kept fixed at 15 $\mathrm{km} / \mathrm{h}$ and the slope was increased by $2 \%$ each minute until fatigue. $\mathrm{HR}_{\max }$ was considered the highest $\mathrm{HR}$ recorded during the exercise test. $\mathrm{VO}_{2 \max }$ was measured by a open-circuit spirometry during the progressive test by a previously calibrated gas analyzer $\left(\mathrm{K}_{4} \mathrm{~B}^{2}\right.$; Cosmed $\left.^{\circledR}\right)$. With the results of the exercise test, a linear regression equation was drafted on an individual basis to establish the $\mathrm{HR} \times \mathrm{VO}_{2}$ ratio. Thus, using this equation and the records of mean $\mathrm{HR}$ of each specific training session, it was possible to determine the $\mathrm{VO}_{2}$ of the athletes from the HR.

The anaerobic threshold was considered like the onset blood lactate acumulation (OBLA). The HR corresponding to the OBLA intensity was obtained in a field test ${ }^{23}$. The test consisted of 2 to 5 runs of $1000 \mathrm{~m}$ at a mean initial speed of $10 \mathrm{~km} / \mathrm{h}$. Sixty to 90 seconds after each run, a digital blood sample was collected $(25 \mu \mathrm{L})$ for the measurement of blood lactate concentration using the Accusport $^{\circledR}$ blood lactate analyzer. The test was interrupted if the blood lactate concentration reached or exceeded $4 \mathrm{mM}$. Otherwise, the volunteer performed another run at a speed that was $1 \mathrm{~km} / \mathrm{h}$ faster. $\mathrm{HR}$ was monitored along the runs and the average was considered for HR determination. The HR corresponding to OBLA was determined by linear interpolation using the Microsoft Excel ${ }^{\circledR}$ software. Based on the $\mathrm{HR} \times \mathrm{VO}_{2}$ ratio and using the HR anaerobic threshold was determined what was the running speed and the corresponding percentage of $\mathrm{VO}_{2 \max }$.

Environmental conditions (dry/wet, temperature) during all training sessions were recorded using a digital 
thermo-hygrometer (Instrutherm, model HT-260). This device was fixed at $100 \mathrm{~cm}$ from the floor and has an error of $\pm 2 \%$ in its measurement.

\section{Statistical Analysis}

The analysis of the effect of training on the plasma concentration of $\alpha$-actin and serum CK activity was performed using the paired Student's t-test. All results are expressed as mean and standard error of the mean (SEM).
The intraclass correlation coefficient (ICC) was used to determine the reliability between the different measure techniques. The level of significance was set at $\mathrm{p}<0.05$.

\section{Results}

Table 1 shows the characteristics of the volunteers.

The table 2 shows the intensity of training microcycles and intensity of the different types of trainings applied along the pre-season.

Table 1. Characteristics of participants $(n=10)$; data expressed as mean \pm SEM

\begin{tabular}{cccccc}
\hline Age & Body mass & $\% \mathrm{~F}$ & \multicolumn{2}{c}{$\mathrm{VO}_{2 \max }$} & \multicolumn{2}{c}{ Anaerobic threshold } \\
& & & & $\mathrm{Vel} / \mathrm{VO}_{2 \max }$ & $(\%)$ \\
\hline (years-old) & $(\mathrm{kg})$ & $(\%)$ & $\left(\mathrm{mlO}_{2} / \mathrm{kg} / \mathrm{min}\right)$ & $(\mathrm{km} / \mathrm{h})$ & $74 \pm 5$ \\
\hline $26 \pm 6$ & $73 \pm 4$ & $9 \pm 2$ & $54 \pm 5$ & $12.8 \pm 3$ & 74 \\
\hline
\end{tabular}

Table 2. Duration and intensity of the training microcycles and intensity of the different types of training; values are expressed as mean $\pm \mathrm{SEM}$

\begin{tabular}{|c|c|c|c|c|c|c|c|c|c|c|}
\hline MICROCYCLES & 1 & 2 & 3 & 4 & 5 & 6 & 7 & TOTAL & MEAN & SD \\
\hline Physical training (min) & 380.0 & 530.0 & 250.0 & 340.0 & 300.0 & 270.0 & 310.0 & 2480 & 340.0 & 94.2 \\
\hline $\begin{array}{l}\text { Matches and friendly } \\
\text { games(min) }\end{array}$ & 0.0 & 0.0 & 90.0 & 180.0 & 90.0 & 90.0 & 90.0 & 540 & 77.1 & 62.1 \\
\hline $\begin{array}{l}\text { Technical/tactical } \\
\text { training (min) }\end{array}$ & 100.0 & 180.0 & 180.0 & 360.0 & 350.0 & 230.0 & 260.0 & 1560 & 237.1 & 94.6 \\
\hline $\begin{array}{l}\text { Total of each microcycle } \\
\text { (min) }\end{array}$ & 480.0 & 710.0 & 520.0 & 880.0 & 740.0 & 590.0 & 660.0 & 4580 & 654.3 & 137.8 \\
\hline $\begin{array}{l}\text { Training sessions } \\
\text { (min/mean) }\end{array}$ & 96.0 & 144.0 & 102.0 & 174.0 & 150.0 & 120.0 & 132.0 & - & 131.1 & 27.6 \\
\hline HR (bpm/mean) & 158.6 & 169.0 & 147.6 & 143.4 & 148.9 & 147.3 & 132.9 & - & 149.7 & 11.4 \\
\hline$\% \mathrm{HR}_{\max }(\% /$ mean $)$ & 80.1 & 85.4 & 74.5 & 72.4 & 75.2 & 74.4 & 67.1 & - & 75.6 & 5.8 \\
\hline$\% \mathrm{VO}_{2 \max }(\% /$ mean $)$ & 70.6 & 78.7 & 62.0 & 58.7 & 63.0 & 61.7 & 50.4 & - & 63.6 & 9.0 \\
\hline
\end{tabular}

Figure 1 illustrates serum CK activity before and after the two-month training period. There was an increase in serum $\mathrm{CK}$ activity after training (PRE: $65.5 \pm$ 4.2 U/L; POST: $435.7 \pm 70.0 \mathrm{U} / \mathrm{L} ; \mathrm{p}=0.0004$ ) for the group as a whole (Figure 1A) as well as individually (Figure 1B).

The data from the Western Blot analysis reveal an evident increase in serum levels of $\alpha$-actin in the posttraining period in relation to the pre-training period (PRE: $42.9 \pm 21.6 \mu \mathrm{g} / \mathrm{mL} ;$ POST: $68.1 \pm 19.1 \mu \mathrm{g} / \mathrm{mL} ; \mathrm{p}=0.0004$, determined from optical density) (Figure 2). $\alpha$-actin quantification using the ELISA technique confirmed this increase for the group as a whole (Figure 3A) (PRE: $70.63 \pm 10.4 \mu \mathrm{g} / \mathrm{mL} ;$ POST: $101.80 \pm 17.3 \mu \mathrm{g} / \mathrm{mL}$; $\mathrm{p}=0.0125$ for pre and post, respectively) as well as individually (Figure 3B). The ICC between the different measurement techniques for $\alpha$-actin was 0.83 . 


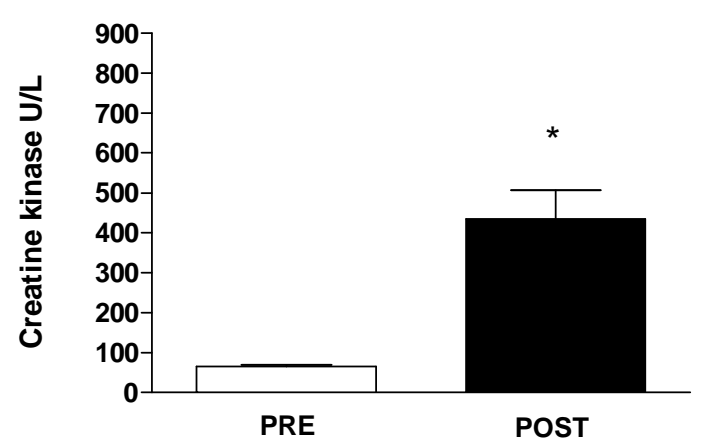

Figure 1. Serum CK activity in U/L; there was a significant increase in CK activity in the overall group. Data expressed as mean \pm SEM, $* \mathrm{p}=0,0004$.

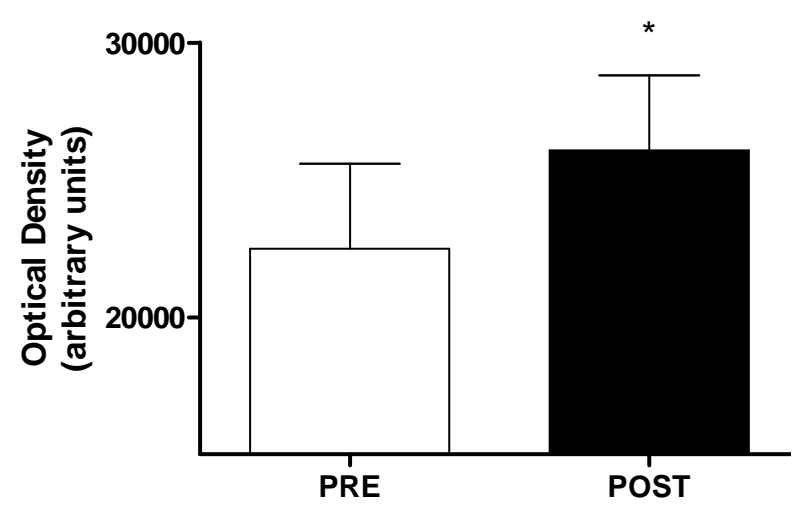

Figure 2. Serum $\alpha$-actin dosage (Western Blot); there was a significant increase in the post-training period; $\alpha$-actin pattern suggests detectable levels are on the order of $\mu \mathrm{g}$; data expressed as mean $\pm \mathrm{SEM}$; * $\mathrm{p}=0,0004$.

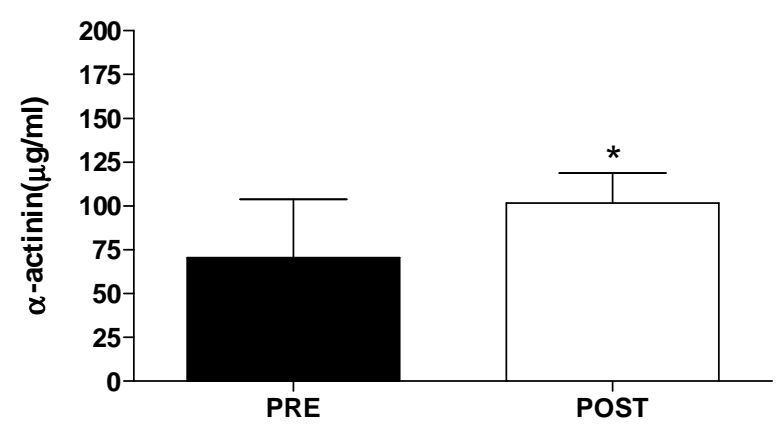

Figure 3. Quantification of serum $\alpha$-actin ELISA; there was a significant increase in the post-training period in the overall group. Data expressed as mean \pm SEM, $* \mathrm{p}=0,0125$.

\section{Discussion}

The main finding of this study was that preseason training caused significant changes in serum CK and $\alpha$ actin. It should also be noted that the behavior of $\alpha$-actin and $\mathrm{CK}$ in response to the physiological demands imposed upon the players in the preseason was similar. The $\alpha$-actin appears to be a good biomarker of physiological stress. No other studies assessing these two physiological parameters in pre-season soccer training were found in the literature.
In a study carried out by Lazarim et al. ${ }^{18}$, CK was used as a marker of muscle overload and recovery status in soccer matches, with mean values of $493 \pm 315 \mathrm{U} / \mathrm{L}$ among players at rest; throughout the season, some athletes presented extreme values over $950 \mathrm{U} / \mathrm{L}$ and were instructed to rest until these values diminished. This type of monitoring demonstrates the applicability of CK as a marker for the early detection of muscle overload after a soccer training period. In the present study, values above $650 \mathrm{U} / \mathrm{L}$ were found in three athletes. CK values were 
changed in all the players, while $\alpha$-actin increased in eight of the ten players, thereby demonstrating a different sensibility pattern between these markers.

In another study, CK was also considered a good marker of training status in athletes, but with reservations, considering the effect of age, gender, race, training status, body composition and disease on the plasma concentrations of this metabolite ${ }^{24}$. Clarkson et al. ${ }^{25}$ evaluated the plasma activity of $\mathrm{CK}$ in healthy students in groups that performed concentric, eccentric and isometric exercises and found an increase in CK activity, with no differences between groups. Thus, experimental evidence reveals that the rise in blood $\mathrm{CK}$ does not necessarily reflect the level of tissue injury, possibly suggesting simply changes in cell membrane permeability and not necessarily physiological demand ${ }^{3}$.

As in previous studies, there was greater serum CK activity (approximately 400\%) at the end of the preseason training period ${ }^{20}$. This result reflects the training and competition profiles imposed on soccer athletes around the world, especially in Brazil. Short training periods and a full calendar of matches make the complete recovery of soccer athletes impossible and lead to these concentrations of muscle injury markers ${ }^{18,26}$. Other authors believe that CK behavior during and after physical exercise may be directly related to individual characteristics, making possible the classification of subjects as either highly responsive or less responsive. According to these same authors, peak CK post-exercise activity in the highly responsive group would be below $3000 \mathrm{U} / \mathrm{l}$, whereas the value in the less responsive group would be below $400 \mathrm{U} / \mathrm{l}^{3,27}$.

The increase on the CK activity may be a result of changes on the membrane of the muscle cell, due to the hypoxia and muscle ischemia reactions originated from the exhaustive exercise, as well as from the increased intracellular calcium, which would activate the proteases dependent on the calcium ${ }^{28}$. Thus, CK seems to be a marker of changes on the metabolic behavior of muscles, possibly indicating injury caused by crushing, tetany and strenuous activities ${ }^{29}$. However, there is controversy in the use of CK regarding its specificity and reliability as a marker of micro-injury originating from muscle overload during physical activity ${ }^{3,25}$.

$\alpha$-actin is another proposed marker of muscle damage $^{21}$, as it is a structural protein of the musculoskeletal system that is released quickly into the blood in cases of muscle damage with no interference from other tissues and it remains at high concentrations for 72 hours. $\alpha$-actin is abundant in the cytoplasm at higher concentrations than other markers and has an isoform specific to skeletal muscle. A previous study reports that $\alpha$-actin has all the characteristics of a good marker for muscle injury and its use in sports is proposed for the control of muscle damage during training ${ }^{6}$. The authors cited found that $\alpha$-actin values increase $140 \%$ in people with muscle damage. In the present study, there was a $100 \%$ increase, demonstrating an increase in injury risk throughout the pre-season training period. In previous studies, the analysis of $\alpha$-actin has been carried out on patients with heart disease $\mathrm{e}^{30,31}$.

The use of $\alpha$-actin as a marker of muscle damage is a response to questions regarding currently used markers. Studies searching for markers of cardiac muscle injury propose the use of contractile proteins of the sarcomere. The authors of these studies propose that, in order to detect muscle injury stemming from the physiological demand imposed by certain activities, such markers should be part of the musculoskeletal structure ${ }^{6}$, 21. $\alpha$-actin is a very early marker of tissue injury, as its release occurs within the first six hours ${ }^{31}$. This kinetics corresponds to a fast, early release of $\alpha$-actin from the cytoplasmic compartment of the cell, which may be followed by the structural component ${ }^{6}$.

The plasma concentration of $\alpha$-actin has been used as a marker of stress level in professional ${ }^{16}$ and college ${ }^{15}$ soccer players and it has been found to be associated to accute physiological demand.

In team sports, the long competitive season is not favorable to the ideal preparation of athletes. This is especially true for soccer, which is considered an intermittent activity of high intensity ${ }^{32}$, in which athletes cover an average of $10 \mathrm{~km}$ during a game, with a mean intensity of $85 \%$ of maximal heart rate and $75 \%$ of 
maximal oxygen consumption ${ }^{13}$. Physiological markers have revealed that recovery is incomplete sometimes $72 \mathrm{~h}$ after a game $e^{17,33}$.

Thus, the determination of physiological parameters for monitoring the training status of athletes is an important factor for planning the sportive preparation. Determining the recovery in response to training stimuli in a reliable and individual fashion is necessary to avoiding excesses and the exclusive use of the subjective perception of trainers and preparers for the selection of training loads.

It should be highlighted that in this study we evaluated a professional soccer team which had an unusual long pre-season, lasting for two months, and the physiological markers indicated that there was a significant overload. It is common in other professional teams occur smaller preparatory periods, whereas the competitive calendar is intense. For this different data can be found in future studies.

The present study undertook the first analysis of $\alpha$ actin in soccer players as a marker of muscle overload stemming from training. The results demonstrate the viability of $\alpha$-actin as a marker of muscle injury, since its response was similar to that of CK. The determination of the kinetics of the release of $\alpha$-actin, critical reference values, its relation with muscle injury and its relation with psychological profile and training load should be further investigated.

\section{Conclusion}

The significant increases in $\alpha$-actin concentration and in CK activity of soccer players over the two-month pre-season indicated that an elevated training overload was imposed upon the athletes

\section{Acknowledgements}

National Committee for Scientific and Technological Development (Conselho Nacional de Desenvolvimento Científico e Tecnológico [CNPq]), Coordination and Improvement of Superior Education Staff (Coordenação de Aperfeiçoamento de Pessoal de Nível Superior [CAPES]), Foundation for Support to
Research in the State of Minas Gerais .(Fundação de Amparo à Pesquisa do Estado de Minas Gerais [FAPEMIG])- and Pro-Rectory of Research of the Federal University of Minas Gerais (Pró-Reitoria de Pesquisa da Universidade Federal de Minas Gerais [PRPQ-UFMG]), Clinical analyses laboratory São Sebastião (Cel Fabriciano, MG) and laboratory management Elias José de Sales Filho and laboratory techincal Marcilene Honorato Pires. 


\section{References}

1. Smith LL. Acute inflammation: the underlying mechanism in delayed onset muscle soreness. Med Sci Sports Exerc 1991;23;542-551.

2. Brown SJ, Child SH, Donnelly AE. Exercise-induced skeletal muscle damage and adaptations following repeated bouts of eccentric muscle contractions. J Sport Sci 1997;15;215-222.

3. Brancaccio P, Maffulli N, Limongelli FM. Creatine kinase monitoring in sport medicine. Br Med Bull 2007;18:209-230.

4. Totsuka M, Nakaji S, Suzuki K, Sugawara K, Sato K. Break point of serum creatine kinase release after endurance exercise. J Appl Physiol 2002;93:1280-1286.

5. Sayers SP, Clarkson PM, Short-Term Immobilization after Eccentric Exercise. Part II: Creatine Kinase and Myoglobin. Med Sci Sports Exerc 2003;35:762-768.

6. Martinez-amat A, Boulaiz H, Prados J, Marchal JA, Padial PP, Caba O, Serrano F, Aranega A. Release of $\alpha-$ actin into serum after skeletal muscle damage. Br J Sports Med 2005;39:830-834.

7. Urhausen A, Kindermann W. Diagnosis of overtraining, what tools do we have? Sports Med 2002;32:95-102.

8. Friden J, Lieber RL. Structural and mechanical basis of exercise-induced muscle injury. Med Sci Sports Exerc 1992;24:521-530.

9. Zoppi CC, Antunes-NETO ., Catanho FO, Goulart LF, Moura NE, Macedo DV. Changes in biomarkers of oxidative stress, antioxidant defense and muscle damage in soccer players during a competitive season. Rev Pau Educ Fís 2003;17:119-30.

10. Komulainen J, Takala TE, Vihko V. Does increased serum creatine kinase activity reflect exercise-induced muscle damage in rats. Int J Sports Med 1995;16:150-154.

11. Bangsbo J. The physiology of soccer - with special reference to intense intermittent exercise. Acta Physiol Scand 1994;619:1-155.

12. Mohr M, Krustrup P, Bangsbo J. Match performance of high-standard soccer players with special reference to development of fatigue. J Sports Sci 2003;21:519-28.

13. Stolen T, Chamari K, Castagna C, Wisløff UU. Physiology of soccer: an update. Sports Med 2005;35:501-536.

14. Ascensao A, Rebelo A, Oliveira E, Marques F, Pereira L, Magalhaes J. Biochemical impact of a soccer match - analysis of oxidative stress and muscle damage markers throughout recovery. Clin Biochem 2008;41:841-51.

15. Coelho D, Pimenta E, Veneroso C, Morandi R, Pacheco D, Pereira E, et al. Assessment of acute physiological demand for soccer. Rev Bras Cineantropom Desempenho Hum 2013;15:667-76.

16. Pimenta E, Coelho D, Cruz I, Morandi F, Veneroso C, de Azambuja Pussieldi G, Carvalho MR, Silami-Garcia E, De Paz Fernández J. The ACTN3 genotype in soccer players in response to acute eccentric training. Eur J Appl Physiol 2012;112(4):1495-503.

17. Ispirlidis I, Fatouros IG, Jamurtas AZ, Nikolaidis MG, Michailidis I, Douroudos I, et al. Time-course of changes in inflammatory and performance responses following a soccer game. Clin J Sport Med 2008;18(5):423-31.

18. Lazarim FL, Antunes-neto JM, Da Silva FO, Nunes LA, Bassini-Cameron A, Cameron LC, Alvez A, Benzikofer R, Marcdo D. The upper values of plasma creatine kinase of professional soccer players during the brazilian national championship. J Sports Sci Med 2009;12:85-90.

19. Filaire E; Bernain X; Sagnol M; Lac G. Preliminary results on mood state, salivary testosterone: cortisol ratio and team performance in a professional soccer team. Eur J App Physiol 2001; 86: 179-184.

20. Coelho D, Morandi R, Melo M, Andrade R, Paixão R, Silami-Garcia E. Analysis of the trends of creatine kinase levels during the preseason of a professional soccer team. Rev Bras Cineantropom Desempenho Hum 2014;16:129-35.

21. Martinez-amat A, Marchal JA, Rodríguez SF, Boulaiz H, Prados JC, Hita CF, Caba O, Carrillo E, Martín I, Aranega A. Role of $\alpha$-actin in muscle damage of injured athletes in comparison with traditional markers. Br J Sports Med 2007;41:442-446.

22. Lowry R., The number and morphology of moss chromosomes. Stain Technol 1954;29:17-20.

23. Eniseler N. Heart rate and blood lactate concentrations as predictors of physiological load on elite soccer players during various soccer training activities. J Strength Cond Res 2005;19(4:799-804. 
24. Brancaccio P, Limongelli FM, Maffulli N. Monitoring of serum enzymes in sport. Br J Sport Med 2006;40:9697.

25. Clarkson PM, Byrnes WC, Mccormick KM, Turcotte LP, White J.S. Muscle soreness and serum creatine kinase activity following isometric, eccentric, and concentric exercise. Int J Sports Med 1986;7:152-155.

26. Mougios V. Reference intervals for serum creatine kinase in athletes. Br J Sports Med 2007;4: 674-678.

27. Newham DJ., Jones DA., Edwards RH. Plasma creatine kinase changes after eccentric and concentric contractions. Muscle Nerve 1986;9:59-63.

28. Moreau D, Dubots P, Boggio V. Effects of electromyostimulation and strength training on muscle soreness, muscle damage and sympathetic activation. J Sports Sci 1995;13:95-100.

29. Sacher RA, Mcpherson RA. Interpretação clínica dos exames laboratoriais [In Portuguese]. Manole, São Paulo 2001.

30. Aránega AE, Reina A, Velez C, Alvarez L, Melguizo C, Aránega A. Circulating $\alpha$-actin in angina pectoris. J Mol Cell Cardiol 1992;29:15-22.

31. Aránega AE, Reina A, Muros MA, Alvarez L, Prados J, Aránega A. Circulating $\alpha$-actin protein in acute myocardial infarction. Int J Cardiol 1993;38:49-55.

32. Bangsbo J. The physiology of soccer - with special reference to intense intermittent exercise. Acta Physiol Scand 1994;619:1-155.

33. Malm C, Ekblom O, Ekblom B. Immune system alteration in response to increased physical training during a five day soccer training camp. J Sports Med 2004;25:471-476. 